\title{
EUROPARTIES IN THE NEIGHBOURHOOD: HOW TRANSNATIONAL PARTY POLITICS BIND EASTERN EUROPE AND THE WESTERN BALKANS TO THE EU Angelos Chryssogelos, London Metropolitan University
}

\section{Version accepted for publication (12 October 2020) in Comparative European Politics}

\begin{abstract}
Transnational European party federations - 'Europarties' - are an overlooked actor of EU external relations despite their strong footprint outside the EU. This article discusses the activities of Europarties as networks of EU external relations closely aligned with the interests and values of EU foreign policy, but conditioned by their character as transnational partisan actors with distinct priorities defined by ideological affinity and political commitments to partner parties. Empirically, the article investigates the activities of the centre-right European People's Party (EPP) in Georgia and North Macedonia, demonstrating how Europarties can act as amplifiers of EU influence in Eastern Europe and Western Balkans, but also how their partisan interests often come into tension with EU priorities. The findings carry implications for the theory and practice of EU relations with its neighbourhood at a time when prospects for further enlargement appear significantly weakened.
\end{abstract}

Keywords: Europarties; EU foreign policy; European People's Party (EPP); Georgia; North Macedonia; European Neighbourhood Policy 


\section{Introduction}

The external relations of the EU are today a dense and multi-layered field where a growing variety of EU actors engages a rising number of stakeholders in neighbouring countries. Even actors associated mostly with the EU's internal governance like the European Parliament have attracted attention for their role in EU foreign and neighbourhood policy (Nitoiu and Sus, 2017; Rosen and Raube, 2018). Yet an increasingly assertive actor both in the EU's internal governance and its external relations has received scant attention: the transnational political party federations more commonly known as 'Europarties'.

This omission is understandable to the extent that transnational party politics have received little research interest (see indicatively Bardi and Calossi, 2009; Bressanelli, 2014; Hix and Lord, 1997; Van Hecke, 2010). But it is still a significant gap since transnational party politics has always formed an important aspect of relations between the EU and neighbouring states. European party federations have historically maintained contacts with parties outside of the EU. And with the EU's enlargement appetite seemingly exhausted, Europarties' ability to engage political actors in post-Soviet and Balkan states must be seen in a new light as the EU tries to maintain influence there.

The question then is twofold: What is the role of Europarties as actors of EU external relations today? And how do their activities relate to more specific objectives of EU foreign, and particularly enlargement and neighbourhood, policy? This article aims to answer these questions by conceptualizing Europarties as networks of external EU governance of a partisan-ideological character. The core insight is that, while Europarties contribute to the EU's goal to strategically bind neighbouring states and foster transformation of their societies, contradictions often emerge. Europarties' external activities are conditioned by their commitment to the goals of EU foreign 
policy. But they are also informed by the logic of partisan allegiance, ideological affinity and electoral gains; indeed, this is why they are able to attract and influence external partisan actors.

In other words, if Europarties' external activities as networks of EU governance can be seen as the pursuit of EU foreign policy goals by partisan-ideological means, Europarties still are conscious actors for whom EU foreign policy is a field for promotion of their own goals. The implication for EU foreign policy is that the involvement of more actors creates new ways for the EU to exert influence abroad, but also complicates its conduct as different political priorities and logics of transnational action contrast conventional diplomatic tools.

The article proceeds as follows: first, it presents the external and internal context of EU politics that has raised the importance of Europarties; second, it develops the concept of partisan-ideological network of external governance to understand Europarties as external actors whose activities both underpin and cut across EU goals in the neighbourhood; third, it applies this framework to the activities of the centre-right European People's Party in Georgia and North Macedonia, focusing on recent political crises that created opportunities for the EPP to act as conduit of EU influence and created tensions between the EPP's objectives and some of the immediate priorities of the EU; fourth, it concludes by discussing the implications of the analysis.

\section{Europarties: Networks of External EU Governance of a Partisan-Ideological Character}

The Context: The EU and the Neighbourhood in a Post-Enlargement (?) Era

To understand the role of Europarties in the EU's external relations, it is important first to assess the context within which they operate, particularly with regards to the EU enlargement 
and neighbourhood policy (ENP). While until 2004 the EU's engagement with its immediate neighbourhood took place through the lens of prospective accession of these states, since then the enlarged EU is facing a much more complex environment with the states bordering it.

The straightforward prospect of enlargement meant that the EU cpuld influence the postcommunist states of Central and Eastern Europe (CEE) to adopt political and economic reforms. Yet the enlargement perspective is either lacking or weakened vis-à-vis the two neighbouring groupings of the EU: the six post-Soviet states comprising the Eastern Partnership (EaP) for whom no enlargement promise has been made; and the six states of the Western Balkans where a formal accession prospect exists but the EU appears very lacklustre to act upon it. This uncertain or absent promise of enlargement weakens the EU's ability to enforce conditionality in its relationship with these countries (Nitoiu, 2017: 89; Schimmelfennig and Scholtz, 2008). Adapting to the EU acquis entails costs for elites that have long benefited from captured states. Without the prospect of EU accession and its rewards, these elites have little incentive to adopt EU rules (Börzel et al, 2017).

In light of this, the EU has explored other ways to exert influence in neighbouring countries. One is to foster societal linkage with these countries' citizens and transformation from below as EU values spread among societies and generate pressure on states and elites to align with the EU (Bosse and Korosteleva-Polglasse, 2009). But civil society in Eastern Europe and the Western Balkans is weak and fragmented, and local elites have the capacity to manipulate it and remain sheltered from its demands (Lavenex and Schimmelfenning, 2011). The EU has also pursued external governance promotion as a substitute for the more formal enlargement process, establishing networks of experts between the EU and the administration of neighbouring states in order to facilitate the transference of policy practices and norms (Lavenex, 2008; Nitoiu, 2017: 
91). Despite an intensification of this method of external engagement, the problems are the same as with societal linkage: the prevalence of oligarchic politics and the weakness of administrative structures (Lavenex and Schimmelfenning, 2011: 896-897).

At the same time, the EU must engage with its neighbourhood at a high political level (Nitoiu, 2017: 92). Its EaP framework has always had a geopolitical undercurrent, since the aim to embed post-Soviet states in its framework of rules and norms means pulling them from the Russian orbit (Nitoiu and Sus, 2017: 74). The EU's normative and geopolitical goals are entwined (Youngs, 2009: 900). In the Western Balkans on the other hand the EU may have an enlargement agenda, but its progress is hampered by legacies of nationalism, including the Serbia-Kosovo tensions and ethnic divisions in Bosnia (Stojić, 2017). Thus, in approaching its neighbourhood the EU must also engage with geopolitical challenges, something that does not always sit easily with the bureaucratic character of its enlargement and neighbourhood policy (Lehne, 2014)

\section{Europarties in EU Politics}

The importance of transnational party politics in the EU has only increased in recent years. Dynamics of integration since Maastricht, accentuated by enlargement and the governance crises of 2010-15 that deepened rifts between member-states, has made trans- and inter-governmental modes of policymaking a dominant feature of the EU modus operandi (Bickerton et al, 2015). By operating on the intersection of intergovernmental and transnational politics (Van Hecke, 2010), transnational party federations are of obvious importance. More practically, the Spitzenkandidat process, whereby since 2014 Europarties put forward candidates for the post of 
Commission president ahead of European elections, has further strengthened their role (Christiansen, 2016).

Even though the notion of Europarty is often used in an abstract and conflated way, sometimes as a byword for 'political family' and ideological affinity across borders, Europarties as such have a distinct corporate identity from other partisan actors of the EU political system like European Parliament groups (Hix and Lord, 1997). Europarties are entities based in Brussels (Lightfoot, 2006). The main ones are the centre-right European People's Party (EPP), the centreleft Party of European Socialists (PES), and the centrist Renew Europe, known until 2019 as Alliance of Liberals and Democrats (ALDE). Far from being genuine supranational parties (Bardi and Calossi, 2009), Europarties are in practice little more than secretariats tasked with representing their member-parties in Brussels, facilitating co-operation (Zur Hausen, 2008) and coordinating EU election campaigns (Gagatek, 2010).

Given that even the biggest Europarties have far fewer resources than even their smallest member-parties and they also lack a mass direct membership (although see Hertner, 2018), they can be understood first and foremost as agents of national political parties (Bardi and Calossi, 2009). Thus, their standing hinges primarily on them delivering coordinating and informationsharing services to their membership. Indeed, Europarties organise meetings of member-party actors and of national ministers belonging to their member-parties ahead of Council sessions, and summits of member-party leaders ahead of European Council meetings. Europarty activities are valuable for member-parties that are not in government in their home country, as politicians in opposition gain proximity to the policymaking process in Brussels and information about developments in various policy dossiers (Chryssogelos, 2017: 258-259). 
Yet these skeletal secretariats in Brussels are also actors in their own right. They are led by politicians, often of high profile (e.g. ex-prime ministers like the EPP's current president Donald Tusk), who are keen to play an important role in EU politics. They are staffed by policy professionals aiming to make a mark in Brussels and use this as an entry point for career opportunities in or around EU institutions. Also, not to be underestimated is the ideational underpinning of Europarty officials, most of whom sincerely seek to infuse European integration with a specific ideological flavour. In all these ways, Europarties are not only reflections of the interests of their member-parties but actors with a non-negligible degree of agency in their own right, motivated by their desire to increase their influence and visibility in the EU political system (Chryssogelos, 2017: 262).

At the same time, Europarties relate with an array of other actors in the EU. Most obviously, Europarties are in a close relationship with their equivalent European Parliament groups that are themselves an arena of competition between national member-parties for political and programmatic influence (Klüver and Rodon, 2013) and, hence, crystallization of Europarties' transnational ideological profile (Bressanelli, 2014). MEPs often occupy positions in Europarty organs, including even the position of Europarty president (as with Joseph Daul as head of the EPP). Beyond the Parliament, Europarty affiliates populate all other major EU institutions. The president and members of the EU Commission of course, but since 2009 also the president of the European Council and since 2019 even the president of the ECB, are all appointed on the basis of their partisan allegiance. These actors now casually attend summits, events and seminars organized by Europarties.

In this expanded sense, Europarty secretariats are also hubs of networks of EU governance. This brings the study of Europarties close to the governance approach of EU politics, whereby 
the formal intergovernmental and supranational modes of policymaking are traversed by policy networks where information, influence and expertise are exchanged (see indicatively Börzel, 2010; Kohler-Koch and Rittberger, 2006). While the governance approach has focused primarily on networks of technical, epistemic or bureaucratic character, the study of Europarties reveals the importance of partisan allegiance and ideological like-mindedness as a feature around which networks running through EU institutions and national political arenas can also coalesce.

\section{Conceptualizing the Actorness of Europarties in EU External Relations}

The above examination of the nature of Europarties in the EU political system provides hints as to their actorness in EU external relations. It is important to remember that Europarties have always had an external aspect in their activities. In the 1990s, they sought partners in CEE and this (fore)shadowed the dynamics of enlargement conditionality (Klápácová, 2013). Just as the EU aimed to reform enlargement countries, Europarties socialised party elites in European norms, helped partner parties consolidate their ideological profile (von dem Berge, 2017) and urged them to stay on the pro-European path. Thus, transnational party politics were an additional avenue for EU influence on candidate states (Pridham, 2014; Vachudova, 2008) because elites in candidate countries valued the benefits of association with them (international exposure and domestic credibility, policy cooperation, campaign assistance) (Klápácová, 2013).

In a post-enlargement context, expansion beyond the EU has been a way for Europarties to increase their collective influence within the EU political system, while also competing with each other for attention in Brussels ${ }^{1}$. For politicians in post-Soviet Europe and the Western Balkans on the other hand, association with Europarties is one of the few opportunities to engage with EU leaders, voice their interests and draw political capital from their contacts with 
European politicians ${ }^{2}$. For elites from countries whose relations with the EU run through the largely bureaucratic framework of enlargement and neighbourhood policy (Nitoiu, 2017: 91), Europarty events are precious opportunities to engage with the EU on a high-political level ${ }^{3}$.

Thus, the relationship between Europarties and affiliated parties in the neighbourhood is to a significant degree reversed compared to the one with their member-parties from inside the EU that remain to a large extent their principals (Bardi and Calossi, 2009). This allows Europarties to act as conduits for the EU's goals in the neighbourhood and claim a role in EU foreign policy. The EU wants to induce political elites in the Western Balkans to resolve pending ethnic disputes and to keep EaP states away from the Russian orbit. Pressure towards these goals in Europarty forums and summits can be an additional tool to influence political developments, as elites from the neighbourhood value the benefits they accrue by satisfying their partners in Brussels ${ }^{4}$. Europarties are also sources of information on foreign affairs for affiliated politicians and policymakers in EU institutions (see also Nitoiu and Sus, 2017: 84; Rosen and Raube, 2018: $80)^{5}$.

Most contemporary literature on EU neighbourhood policy is explicitly pessimistic about the prospects of the EU inducing domestic change in the Western Balkans and Eastern Europe without the promise of enlargement (Börzel et al, 2017; Richter and Wunsch, 2020). Stojić (2017: 220-221) has found that Europarty influence over the strategic decisions of their memberparties in the Balkans is limited, while Shagina (2017) is quite sceptical whether Europarties contribute to transference of norms and practices of democratic party politics in Ukraine. Whether Europarties strengthen democracy at all is even put into question regarding EU members like Hungary (Kelemen, 2017; Meijers and van der Veer, 2019), which in turn relates 
to critical views of EU influence on democracy and rule of law in the neighbourhood (Richter and Wunsch, 2020).

Valid as these concerns are, a more complete view of Europarty agency beyond the control of their member-parties and their multifaceted activities as political networks showcases aspects of their role that mostly remain underappreciated. Thus, the conditionality they apply on affiliated parties that crave for Europarty association can be an important substitute for EU leverage in the neighbourhood (Chryssogelos, 2017: 262-264; Vachudova, 2014). Europarties expect their associated parties to display at least some ideological congruence with their values, have internal structures that are reasonably open and democratic (von dem Berge, 2017), as well as be (relatively) free of association with major corruption charges. Most importantly, Europarties expect associated parties to unequivocally commit to their countries' EU perspective ${ }^{6}$. Failure of associate parties in the neighbourhood on one or more of these fronts has led in the past to their sanction and even expulsion from Europarties.

It is also important to note that, next to their self-interested goals (namely, to increase their visibility and influence), Europarties have ideational objectives. As EU actors, they identify with the interests of the EU in international affairs, while as partisan-ideological actors they aim to formulate distinct programmatic positions on EU external relations (Chryssogelos, 2015). In both senses, Europarties use their affiliation with parties in the neighbourhood as a tool to bring about specific foreign policy outcomes: further EU goals in the region and, within this framework, support likeminded partners and promote priorities specific to their ideological identity.

In order to make sense of the actorness of Europarties in EU external relations that reflects their multifaceted nature - umbrellas of national parties, distinct actors with their own corporate identity and interests, hubs of networks of governance - I propose to combine two conceptual 
perspectives. The first is the concept of transnational actors as developed in the transnational relations literature to capture Europarties' role as distinct actors in their own right. The interest in transnational actors after the end of the Cold War arose from the awareness that non-state actors have the ability, flexibility and ideational acumen to pursue international goals and effect change by propagating new ideas or expertise across official jurisdictions. (Evangelista, 1995; RisseKappen, 1995). At the same time, transnational actors may also pursue goals that conform with the interests of formal actors of international relations like states or international organisations that they are affiliated with (Risse, 2007: 260).

Transnationalism is of course a defining feature of Europarties inside the EU (Van Hecke, 2010), and the same principle extends beyond EU borders, with Europarties binding together political parties across national jurisdictions (Chryssogelos, 2017: 259-260; Fonck, 2018: 1306). As legal entities with a close relationship with EU institutions and ideationally committed to the broad framework of EU foreign policy goals - regional stability and security, attraction of postSoviet and Western Balkan states to the EU orbit countering rival geopolitical influences (Chryssogelos, 2017: 259) - Europarties can influence the neighbourhood through transnational channels that complement conventional EU diplomacy (Nitoiu and Sus, 2017: 84).

But despite the close alignment of Europarty objectives with EU foreign and neighbourhood policy goals, Europarties can be understood as transnational actors also because they maintain their distinct goals, priorities and logic of operation (Fonck, 2018: 1306-1307). A key source of Europarties' credibility and leverage towards their external partners is their ability to defend and promote the latter's interests in Brussels and display partisan allegiance to their partners. While they operate within the general framework of EU strategic interests and norms of external 
relations, Europarties remain in the final analysis partisan actors engaged in partnerships defined by adherence to a set of ideological goals and principles.

Thus, Europarties not only amplify EU influence in the neighbourhood but also serve their transnational purpose of partisan and ideological allegiance. Despite their formal adherence to EU goals, Europarties cannot cease to perform their partisan function, because it is precisely their ability to satisfy partner parties' needs that they consider as precondition for exerting leverage and influence over elites in neighbouring countries. In other words, Europarties are in a dynamic relationship with EU foreign and neighbourhood policy: they are constrained by it but also use it as a field for the pursuit of goals dictated by their transnational nature (Fonck, 2018: 1309).

The view of Europarties as networks in the EU political system also has implications for their external actorness, especially since EU-neighbourhood relations are increasingly understood through the lens of external governance promotion. In this perspective, the EU aims to transpose norms and practices of policymaking to states in the Balkans and the Eastern Partnership through transgovernmental networks of experts, bureaucrats and administrators (Lavenex and Schimmelfennig, 2011). Here as well, Europarties' ability to foster ties with politicians, cadres and experts in the neighbourhood on the basis of partisan affinity also creates horizontal networks of norm and practice transference in the area of representative politics, party organization, state-society relations etc. Much as inside the EU then, Europarties can be considered as networks of external EU governance as well (Chryssogelos, 2017).

Bringing these two theoretical threads together, we can begin to understand Europarties in EU foreign policy as networks of external EU governance of a partisan-ideological nature. Europarties influence, socialise and shape the conduct of political actors in the neighbourhood in 
return for access to the EU policymaking system and opportunities to promote their profile in Brussels, an important source of EU leverage at a time of weakened credibility of the prospect of enlargement (Börzel et al, 2017). But despite their close alignment and reference to EU strategic goals in the Balkans and post-Soviet Eastern Europe, Europarties also have a distinct selfconception of interests, priorities and modes of interaction across jurisdictions. This means that, as self-conscious actors of a transnational partisan character, Europarty priorities and logic of operation can theoretically come into conflict with EU objectives and norms. As we will see, such contradictions do indeed arise, affecting the cohesion of EU policy towards its neighbourhood.

\section{The European People's Party in Georgia and North Macedonia}

The centre-right European People's Party (EPP) is the largest Europarty and has the most extensive network of associated parties in the EU neighbourhood. The enlargement of the EPP footprint beyond the borders of the EU is the externalisation of a deliberate strategy of expansion that the EPP undertook in parallel with successive EU enlargements since the early-1990s (Martens, 2008). Having established itself as the largest Europarty in the EU by the early-2000s, the EPP became an attractive partner for elites in neighbouring countries.

Foreign policy considerations have not been unimportant in these dynamics. The EPP benefits from its very strong positioning on foreign and security policy issues (Chryssogelos, 2015). As heir to the legacy of Christian-democracy, the EPP appears as an obvious partner for pro-European parties in neighbourhood countries whose societies still exhibit a socially conservative outlook. At the same time, the Atlanticism of the EPP matches the priorities of proWestern parties in countries with pressing questions of territorial integrity vis-à-vis Russia. These considerations, and especially a candidate party's European orientation, are the most 
important objectives of EPP fact-finding missions to establish ties with parties in the neighbourhood ${ }^{7}$. Here, the goals of the EPP as a transnational ideological actor work in tandem with dynamics of EU conditionality and the goals of EU foreign policy.

At the same time, the programmatic and organisational streamlining that the EPP expects from its associated parties matches the external normative agenda of the EU: projecting European standards of party democracy helps stabilise weak and fickle party systems and creates a better environment for other reforms in neighbouring countries' states and institutions to take place (Chryssogelos, 2017: 263). This is particularly important for countries where party politics are weakly institutionalised and parties are often captured by oligarchic interests, as is the case in post-Soviet states (Bunce and Wolchik, 2010: 61; Hale, 2006: 309; for a good overview, see Bader, 2010: 75-107). In the Western Balkans on the other hand party politics are riven by the legacies of ethnic conflicts (Stojić, 2017), while in this region as well problems with corruption and private capture are also present (Stojarova and Emerson, 2013).

I examine the activities of the EPP as a network of external EU governance of a partisanideological nature in Georgia and North Macedonia. These two cases present appropriate degrees of similarity and difference to comparatively examine the role of a Europarty as actor of EU external relations. Both countries are in the EU neighbourhood, but while North Macedonia is subject to the enlargement perspective that the EU has extended to the West Balkans, as member of the Eastern Partnership Georgia angles for closer relations to the EU without a formal promise of accession. Both countries have fairly stable party politics in comparison to their neighbours. Georgia underwent in 2012-13 the first peaceful change of government in the post-Soviet world, while North Macedonia's party system is dominated by two parties competing along left-right 
ideological lines. Also, despite their deep polarization, major parties in both countries are formally committed to their countries' pro-European orientation.

In terms of methodology, my research relies on a combination of analysis of secondary documents (official releases and press reports) and primary research: six interviews with officials of the EPP in Brussels and of EPP associate parties in Skopje and Tbilisi in the fall of 2018 (complemented by five interviews with Europarty officials conducted in 2013 during a previous research project where I looked more in depth at the Georgian case), and participant observation at policy events and meetings of the EPP network over the decade since 2010. The analysis will first discuss the functioning of the EPP as a network performing functions of socialization, norm promotion and societal influence in the two countries. Then it will discuss how this function is both enhanced and complicated by the EPP's transnational partisan character as it tries to reconcile promotion of EU strategic goals with its commitment to political support to partners.

\section{The EPP as Network of External EU Governance}

The EPP is associated in Georgia with the United National Movement (UNM) and in North Macedonia with VMRO-DPMNE. Even though they are not full members of the EPP (a status reserved for parties from EU member-states), they are involved in the various activities of its network. Both parties' leaders are invited to EPP conferences, congresses and summits. Their representatives take part in some EPP committee and working group sessions and participate in training seminars and policy events organised by the EPP or associated political foundations (e.g. the Konrad Adenauer Foundation) $)^{8}$. Representatives of their youth leagues participate in training events of relevant EPP associations (YEPP for youth and EDS for students) ${ }^{9}$. Nationals of Georgia and North Macedonia work in EPP headquarters in Brussels. The EPP in turn offers 
support to UNM and VRMO by disseminating their positions and assists in their electoral campaigns by issuing video statements of European centre-right leaders, social media posts etc.

This outline of activities demonstrates how the externalisation of the EPP network complements the usual avenues through which the EU has tried to influence its neighbourhood (Lavenex and Schimmelfennig, 2011; Schimmelfenning and Scholtz, 2008). The EPP's involving in its network elites, officials and supporters of UNM and VMRO helps socialise them to European values and expectations of 'normal' party politics ${ }^{10}$. It also contributes to policy and expertise transference as many of the participants in EPP activities may occupy in the future positions in these countries' administration. Finally, the EPP network serves as a venue of linkage between the EU and politically mobilised sections of societies of Georgia and North Macedonia.

In Georgia, UNM was founded by Mikhail Saakashvili and came to power in 2003 with an explicit agenda of modernising Georgia and bringing it closer to the West and away from Russia. It joined the EPP in September 2008, prompted by the Russian invasion of Georgia (Chryssogelos, 2017: 267). After almost a decade in power, in 2012-13 parliamentary and presidential elections removed Saakashvili and his allies from all levels of government in the first orderly handover of power in the post-Soviet world. As Saakashvili accused the new government of engaging in political purges and manipulating justice against him, the EPP voiced his claims in Brussels (EurActiv, 2013).

For years Saakashvili remained a fixture in EPP events (although recently he has fallen out of favour of the EPP $)^{11}$. But UNM continues to highlight its connections with the EPP hoping to draw political capital and support in its electoral campaigns ${ }^{12}$. The EPP's continuing support for UNM (see e.g. EPP, 2015; 2016) has contributed to the survival of an ex-governing party, an 
extremely rare phenomenon in post-Soviet states where parties usually fizzle out when they lose access to state resources (Bader, 2010). For UNM politicians its survival was a precondition to continue to draw on EPP support and maintain access to EU leaders and policymakers ${ }^{13}$. Indirectly, EPP involvement has assisted in consolidating the party system in Georgia, a development congruent with the EU's normative agenda of more stable representative politics in neighbourhood states (Chryssogelos, 2017: 268).

In North Macedonia, VMRO-DPMNE had been in power since 2006 under the leadership of Nikola Gruevski. Although in the beginning Gruevski posed as a pro-European and proAtlanticist reformer who, despite his party's nationalism, could be moderate on inter-ethnic relations, these hopes were dashed. Around the end of his first term in office, Gruevski's government started to propagate an increasingly aggressive form of nationalism externally while slowly establishing more authoritarian forms of rule domestically. In early 2015 a wiretapping scandal threw the country in a major two-year-long political crisis.

Since the two sides of the crisis were associated with different Europarties (EPP and PES), the European Parliament undertook to mediate between them. The effectiveness of this mediation mission however was undermined by the perceived bias of representatives of the EPP network (MEPs and Europarty officials) in favour of VMRO. Indeed, VMRO solicited EPP support to 'shield itself from accusations by the opposition and the international community' (Fonck, 2018: 1317). What is more, the EPP displayed an impressive commitment to Gruevski (Euractiv, 2015). Even after he stepped down as PM in early 2016, EPP actors, both of the Europarty and its wider network, vocally supported VMRO in the December 2016 election $^{14}$. While members of VMRO's liberal wing had contacts with EU actors, the EPP leadership refused to meet them while Gruevski was still leading $\mathrm{VMRO}^{15}$. 
The conduct of EPP towards VMRO visibly changed after June 2018 when the new socialist government in Skopje signed an agreement with Greece resolving the name-issue and opening the way for (the now officially renamed) North Macedonia to begin accession negotiations with the EU. The agreement was heartily endorsed by the EU. Suddenly VMRO, that had replaced Gruevski as leader a few months before, saw its relationship with the EPP freeze, especially after it organised a boycott of a referendum on the name-deal in September $2018^{16}$. The EPP now became interested in the moderate wing of VMRO, inviting its representatives to its conference in Helsinki in November 2018 and meet EPP-affiliated enlargement commissioner Hahn.

The fluctuations in the EPP's stance towards VMRO highlight another dimension of the network function of Europarties' external activities. Gruevski could draw on personal contacts in the EPP network that he cultivated in more than a decade of participation in EPP activities, not only with Brussels actors but also national likeminded politicians, especially Hungarian leader Viktor Orban. With him removed, VMRO became more exposed to EPP criticisms of its domestic and foreign policy positions, so much so that some speculate that if Gruevski were still leading VMRO EPP criticism of its rejection of the name-deal with Greece would have been less voca $^{17}$. On the other hand, the EPP network created opportunities for the EU to come into contact with new, more accommodating actors in VMRO's liberal wing, politicians who themselves had a long history attending EPP events, youth meetings and training seminars in Skopje and Brussels ${ }^{18}$.

\section{The EPP as Transnational Actor of Partisan-Ideological Nature}

While the EPP as a network of external governance has been instrumental in incorporating political actors from the neighbourhood in processes of deliberation, socialization and norm 
diffusion with the aim of transforming the conduct of party politics and influence political developments there, the EPP as a transnational actor defined by its credibility as a partisanideological partner has found itself in a delicate relationship with EU priorities in the region. In both Georgia and North Macedonia, the instincts of the EPP during political crises has been to stick by its partners, often at significant reputational cost and against the positions of important national member-parties and of EU priorities in the region.

In Georgia after 2012 the EPP has been a prominent voice of suspicion in Brussels towards the Georgian Dream coalition that displaced the UNM. As a peaceful electoral change in a postSoviet state, Georgian Dream's victory over the UNM furthered the EU's preference for more stable democratic politics in Georgia, especially since the new government kept on the same proWestern route as Saakashvili. But the EPP regardless voiced concerns against the new government, not least because the other two Europarties - the socialist PES and the liberal ALDE - had partners in Georgian Dream and expressed their support for them.

The Georgian transfer of power in 2012-13 then created a dynamic whereby the EPP's function as a transnational partisan actor contradicted goals and priorities of EU foreign policy, as well as its own role as an EU network fostering norms of democratic governance and competitive party politics. For example, the EPP complicated the EU granting to Georgia visa liberalisation, which it achieved in 2017, a move many interpreted as way to prop up UNM against the government in Tbilisi (EPP, 2016). As a Georgian expert not otherwise unfriendly to the EPP stated, the EPP's instinctive commitment to UNM hampers the development by the EU of 'a broader strategic vision for the region and keeps it from contributing to a stable political culture in Georgia ${ }^{19}$. 
Similar dynamics appeared in the EPP's relationship with VMRO at the time of the wiretap scandal. By that point, VMRO had become an embarrassment for the EPP and exposed it to the criticism of its opponents in Brussels that it contained in its ranks a partner with authoritarian tendencies (European Western Balkans, 2017). The defence of the EPP was that it was much better to keep VMRO in the fold and influence its conduct via EPP procedures and vetting ${ }^{20}$. By expelling VMRO, the EPP and by extension the EU would lose all leverage over Gruevski at a time when the frustration of North Macedonia's accession bid had already weakened the EU's influence in Skopje (Fonck, 2018: 1311). Following on this, an even bigger fear was that expelling VMRO would force it to look for new geopolitical partners altogether, in particular Russia.

The VMRO case sheds light on the complex and contradicting dynamics of the relationship between EU foreign policy priorities and Europarties' commitments as transnational actors. The EPP seemed willing to absorb reputation costs and prioritise partisan allegiance over EU goals during the constitutional crisis in North Macedonia in 2015-17 by sticking by Gruevski. But once a tangible opportunity arose in 2018 for the name-issue to be resolved and the EU to unlock the accession process of North Macedonia, the EPP prioritised the EU's strategic interests over partisan solidarity with the VMRO, urging the party to reassess its nationalistic position on the name-issue lest North Macedonia's path towards the EU be jeopardised ${ }^{21}$.

But EU foreign policy goals may not be the full explanation for the EPP's reversal of position vis-à-vis VMRO. For some observers, the EPP started changing its position and favouring the liberal wing in VMRO already in March 2017 i.e. well before the name-deal with Greece but after Gruevski was removed from power ${ }^{22}$. This showed how an associate party's entrenchment in governmental power helped it to counterbalance the EPP's clout precisely 
because it corresponded to the EPP's logic of operation as a partisan actor sensitive to questions of office-seeking and political success ${ }^{23}$. At the same time, as a transnational actor interested in extending its influence abroad, the EPP considers questions of power (of its members in the EU as well as of its associates outside of it) essential. This qualifies indeed the degree of leverage Europarties as EU actors can exert over elites in the neighbourhood (see also Cianciara, 2016; Richter and Wunsch, 2020).

\section{Conclusions}

Transnational party politics are an overlooked feature of EU external relations. This article has shown that Europarties can serve as both an amplifier of EU influence in its neighbourhood and a factor of contradictions and complications in EU external relations. The activities of the EPP in Georgia and North Macedonia showed that Europarties play an important role as alternative pathways of EU influence over countries in the neighbourhood, helping to promote both the EU's strategic interests and its normative agenda. However, the partisan nature of this type of transnational politics also means that party-political considerations cut across the conduct of EU foreign and neighbourhood policy. The article developed the concept of network of EU external governance of a partisan-ideological character to capture the strengths and contradictions of the actorness of Europarties in EU external relations.

As was shown, in crucial moments the EPP supported controversial politicians like Saakashvili in Georgia and Gruevski in North Macedonia at no small cost for its reputation. While the EPP maintains a large degree of leverage over its partners, its partisan and personal commitments to them may at times run against its support for the strategic goals of the EU. Solidarity with political friends is a sticky and persistent instinct. As an EPP official put it, the 
mindset can be summarised as: 'they may be bastards, but they're our bastards' ${ }^{24}$. But, as the conduct of the EPP towards VMRO showed, there are limits to this mindset when core EU interests come into play and neighbourhood elites lose access to state power.

At the same time, it is important to appreciate the full role of Europarty networks of deliberation, socialization, linkage and norm and policy transference beneath the level of high politics (von dem Berge, 2017). Throughout this period the EPP has provided an important forum for UNM and VMRO cadres to meet EU actors, become socialized in EU norms and be exposed to European standards of party democracy and democratic governance. The hope is that, as these young cadres assume leadership roles in the future, these norms will eventually be put into practice ${ }^{25}$. EPP support contributed to the institutionalization of the Georgian party system (however polarized) after the government change of 2012-13, and it may perhaps contribute to an amelioration of party politics in North Macedonia through fostering a more liberal wing in VMRO.

The analysis has implications for a variety of literatures. In the EU external relations literature, it calls for a broader understanding of the role of external networks of governance, calling for a closer look not only at administrative and expert networks but also partisan and ideological ones. On Europarties, it highlights the analytical distinction between Europarties as entities in Brussels with their own agenda and interests, and Europarties as networks (Bressanelli, 2014; Klüver and Rodon, 2013). The article also extends the literature on the relationship between Europarties and non-EU partners. The analysis broadly agrees with the reservations of Shagina (2017) and Stojić (2017), but shows that conceptualizing Europarties as networks of EU external relations means both appreciating the positive impact they can have 
below the high-politics level and understanding better when and why they may complicate the conduct of EU foreign policy.

Finally, the analysis speaks to a growing literature examining critically the relationship between Europarties and democracy in the EU (Kelemen, 2017) that has worrying analogies with developments in the neighbourhood, as admitted by Europarty and national party officials from the region ${ }^{26}$. This falls within a broader debate about the EU's ability to truly foster change in the neighbourhood (Börzel et al, 2017) as elites there have become more adept at using association with the EU to their benefit (Cianciara, 2016; Richter and Wunsch, 2020; Shagina, 2017).

These are valid criticisms, and the analysis here has shown how they play out in Europarties' transnational activities. But the article has also shown that these negative trends coexist with Europarties' ability under certain conditions to influence developments and their continuous role as networks that contribute, however slowly, to more democratic party politics in the EU neighbourhood. The concept of external network of partisan-ideological character thus locates the activities of Europarties in the framework of post-enlargement EU foreign policy, putting their role in a much different light from the one of internal EU politics and highlighting dimensions of EU engagement with the neighbourhood that are until today understudied and undertheorized.

\section{Notes}


1 Interview with EPP official, Brussels, 18 July 2013. Interview with PES official, Brussels, 11 July 2013.

2 Interview with ex-UNM cadre, Brussels, 15 November 2018.

3 Interview with ex-VMRO member, Skopje, 16 November 2018.

4 Interview with ex-VMRO member, Skopje, 16 November 2018.

5 Interview with PES official, Brussels, 11 July 2013.

6 Interview with EPP official, Brussels, 26 November 2018.

7 Interview with EPP official, Brussels, 26 November 2018.

8 Interview with EPP official, Brussels, 26 November 2018. Interview with VMRO cadre, Skopje, 28 November 2018.

9 Interview with VMRO cadre, Skopje, 27 November 2018.

10 Interview with ex-UNM cadre, Brussels, 15 November 2018.

11 Interview with EPP official, Brussels, 26 November 2018.

12 Interview with ex-UNM cadre, Brussels, 15 November 2018.

13 Interview with ex-UNM cadre, Brussels, 15 November 2018.

14 Interview with EPP official, Brussels, 26 November 2018.

15 Interview with VMRO cadre, Skopje, 28 November 2018.

16 Interview with VMRO cadre, Skopje, 27 November 2018.

17 Interview with VMRO cadre, Skopje, 28 November 2018.

18 Interview with VMRO cadre, Skopje, 28 November 2018.

19 Interview with ex-UNM cadre, Brussels, 15 November 2018.

20 Interview with EPP official, Brussels, 26 November 2018.

21 Interview with ex-VMRO member, Skopje, 17 November 2018. Interview with VMRO cadre, Skopje, 28 November 2018.

22 Interview with EPP official, Brussels, 26 November 2018.

23 Interview with ex-VMRO member, Skopje, 16 November 2018.

24 Interview with EPP official, Brussels, 26 November 2018.

25 Interview with EPP official, Brussels, 26 November 2018. Interview with ex-UNM cadre, Brussels, 15 November 2018.

26 Interview with EPP official, Brussels, 26 November 2018. Interview with ex-VMRO member, Skopje, 17 November 2018.

\section{References}

Bader, M. (2010) Against All Odds: Aiding Political Parties in Georgia and Ukraine. Amsterdam: University of Amsterdam PhD Thesis. 
Bardi, L. and Calossi, E. (2009) Models of Party Organization and Europarties. In DeBardeleben, J. and Pammett, J.H. (eds.) Activating the Citizen: Dilemmas of Participation in Europe and Canada. Houndmills: Palgrave Macmillan, pp. 151-171.

Bickerton, C.J., Hodson, D. and Puetter, U. (eds.) (2015) The New Intergovernmentalism: States and Supranational Actors in the Post-Maastricht Era. Oxford: Oxford University Press.

Börzel, T. (2010) European Governance: Negotiation and Competition in the Shadow of Hierarchy. Journal of Common Market Studies 48(2): 191-219.

Börzel, T.A., Dimitrova A. and F. Schimmelfennig (2017) European Union Enlargement and Integration Capacity: Concepts, Findings, and Policy Implications. Journal of European Public Policy 24(2): 157-176.

Bosse, G. and Korosteleva-Polglasse, E. (2009) Changing Belarus? The Limits of EU Governance in Eastern Europe and the Promise of Partnership. Cooperation and Conflict 44(2): 143-165.

Bressanelli, E. (2014) Europarties After Enlargement: Organization, Ideology and Competition. London: Palgrave Macmillan.

Bunce, V.J. and Wolchik S.L. (2010) Defeating Dictators: Electoral Change and Stability in Competitive Authoritarian Regimes. World Politics 62(1): 43-86.

Christiansen, T. (2016) After the Spitzenkandidaten: Fundamental Change in the EU's Political System? West European Politics 39(5): 992-1010.

Chryssogelos, A.-S. (2015) Patterns of Transnational Partisan Contestation of European Foreign Policy. European Foreign Affairs Review 20(2): 227-245.

Chryssogelos, A.-S. (2017) Transnational European Party Federations as EU Foreign Policy Actors: The Activities of Europarties in Eastern Partnership States. Journal of Common Market Studies 55(2): 257-274.

Cianciara, A.K. (2016) 'Europeanization' as a Legitimation Strategy of Political Parties: the Cases of Ukraine and Georgia. Southeast European and Black Sea Studies 16(3): 391-411. 
EPP (2015) The Backsliding of Democracy in Georgia: Emergency Resolution adopted at the EPP Congress, Madrid, 21st-22nd October 2015, https://www.epp.eu/papers/the-backsliding-ofdemocracy-in-georgia/.

EPP (2016) Georgian government must deliver on European standards for a better future for the country. Tbilisi, 1 April 2016, https:/www.epp.eu/press-releases/georgian-government-mustdeliver-on-european-standards-for-a-better-future-for-the-country/.

EurActiv (2013) War of Letters Reveals Georgia's Political Tensions. 12 March 2013, https://www.euractiv.com/section/europe-s-east/news/war-of-letters-reveals-georgia-s-politicaltensions/.

EurActiv (2015) European parties add fuel to fire in Macedonia. 18 May 2015, https://www.euractiv.com/section/elections/news/european-parties-add-fuel-to-fire-inmacedonia/.

European Western Balkans (2017) S\&D Leader Pittella Calls on Sanctions, Questions VMRODPMNE Membership in EPP. Brussels, 29 April 2017, https://europeanwesternbalkans.com/2017/04/29/sd-leader-pittela-calls-on-sanctions-questionsvmro-dpmne-membership-in-epp/.

Evangelista, M. (1995) The Paradox of State Strength: Transnational Relations, Domestic Structures and Security Policy in Russia and the Soviet Union. International Organization 49(1): 1-38.

Fonck, D. (2018) Parliamentary Diplomacy and Legislative-Executive Relations in EU Foreign Policy: Studying the European Parliament's Mediation of the Macedonian Political Crisis (2015-17). Journal of Common Market Studies 56(6): 1305-1322.

Gagatek, W. (2010) European Political Parties as Campaign Organizations: Towards a Greater Politicization of European Parliament Elections. Brussels: Centre for European Studies.

Hale, H.E. (2006) Democracy or Autocracy on the March? The Colored Revolutions as Normal Dynamics of Patronal Presidentialism. Communist and Post-Communist Studies 39: 305-329. 
Hertner, I. (2018) United in Diversity? Europarties and their Individual Members' Rights. Journal of European Integration, advance online publication, doi: 10.1080/07036337.2018.1513500.

Hix, S. and C. Lord (1997) Political Parties in the European Union. New York: Macmillan.

Kelemen, R.D. (2017) Europe's Other Democratic Deficit: National Authoritarianism in Europe's Democratic Union. Government and Opposition 52(2): 211-238.

Klápácová, L. (2013) The Role of European Political Parties as Actors of European Union's Conditionality. Case Study: EU Conditionality Actorness of the European People's Party. Bratislava: Comenius University PhD Thesis.

Klüver, H. and T. Rodon (2013) Explaining Policy Position Choice of Europarties: The Effect of Legislative Resources. British Journal of Political Science 43(3): 629-650.

Kohler-Koch, B. and Rittberger, B. (2006) The "Governance Turn" in EU Studies. Journal of Common Market Studies 44 (Annual Review): 27-49.

Lavenex, S. (2008) A Governance Perspective on the European Neighbourhood Policy: Integration Beyond Conditionality? Journal of European Public Policy 15(6): 938-955.

Lavenex, S. and F. Schimmelfenning (2011) EU Democracy Promotion in the Neighbourhood: From Leverage to Governance? Democratization 18(4): 885-909.

Lehne, S. (2014) Time to Reset the European Neighbourhood Policy. Brussels: Carnegie Europe.

Lightfoot, S. (2006) The Consolidation of Europarties? The 'Party Regulation' and the Development of Political Parties in the European Union. Journal of Representative Democracy 42(4): 303-314.

Martens, W. (2008) Europe: I Struggle, I Overcome. Brussels: Springer.

Meijers, M.J. and H. van der Veer (2019) MEP Responses to Democratic Backsliding in Hungary and Poland. An Analysis of Agenda-Setting and Voting Behaviour. Journal of Common Market 
Studies 57(4): 838-856.

Nitoiu, C. (2017) Framing the EU's Policy towards the Neighbourhood: The Strategic Approach of the Seventh European Parliament (2009-2014). Cambridge Review of International Affairs 30(1): $87-104$.

Nitoiu, C. and Sus, M. (2017) The European Parliament's Diplomacy - a Tool for Projecting EU Power in Times of Crisis? The Case of the Cox-Kwasniewski Mission. Journal of Common Market Studies 55(1): 71-86.

Pridham, G. (2014) Comparative Perspectives on Transnational Party-Building in New Democracies: The Case of Central and Eastern Europe. Acta Politica 49(1): 30-50.

Richter, S. and N. Wunsch (2020) Money, Power, Glory: The Linkages between EU Conditionality and State Capture in the Western Balkans. Journal of European Public Policy 27(1): 41-62.

Risse, T. (2007) 'Transnational Actors and World Politics'. In Zimmerli, W. et al (eds.) Corporate Ethics and Corporate Governance. Berlin: Springer, pp. 251-286.

Risse-Kappen, T. (ed.) (1995) Bringing Transnational Relations Back In: Non-State Actors, Domestic Structures and International Institutions. Cambridge: Cambridge University Press.

Rosen, G. and Rauben, K. (2018) Influence beyond Formal Powers: The Parliamentarisation of European Union Security Policy. British Journal of Politics and International Relations 20(1): $69-83$

Schimmelfenning, F. and Scholtz, H. (2008) EU Democracy Promotion in the European Neighbourhood: Political Conditionality, Economic Development and Transnational Exchange. European Union Politics 9(2): 187-215.

Shagina, M. (2017) Joining a Prestigious Club: Cooperation with Europarties and Its Impact on Party Development in Georgia, Moldova, and Ukraine 2004-2015. Stuttgart: ibidem Press.

Stojarova, V. and Emerson P. (2013) Party Politics in the Western Balkans. New York: Routledge. Stojić, M. (2017) Party Responses to the EU in the Western Balkans: Transformation, Opposition or Defiance? London: Palgrave Macmillan. 
Vachudova, M.A. (2008) Tempered by the EU? Political Parties and Party Systems Before and After Accession. Journal of European Public Policy 15(6): 861-879.

Vachudova, M.A. (2014) EU Leverage and National Interests in the Balkans: The Puzzles of Enlargement Ten Years On. Journal of Common Market Studies 52(1): 122-138.

Van Hecke, S. (2010) Do Transnational Party Federations Matter? (...And Why Should We Care?) Journal of Contemporary European Research 6(3): 395-411.

von dem Berge, B. (2017) Europarty Eastern Enlargement: An Empirical Analysis of Europarty Influence on Central and Eastern European Parties and Party Systems. East European Politics 33(4): 472-495.

Youngs, R. (2009) Democracy Promotion as External Governance? Journal of European Public Policy 16(6): 895-915.

Zur Hausen, C. (2008) Der Beitrag der 'Europarteien' zur Demokratisierung der Europaischen Union. Marburg: Tectum. 